\title{
Contraceptive Use in East Timorese Ex-Refugee Women in Indonesia: Determinants and Barriers
}

\author{
Maria Paula Marla Nahak'), Maria Lupita Nena Meo²), Maria Getrida Simon3) \\ 1)Nursing Study Program, Universitas Citra Bangsa, Kupang, Indonesia \\ 2)Nursing Study Program, Universitas Sam Ratulangi, Manado, Indonesia \\ 3)Nursing Study Program, UNIKA Santu Paulus, Ruteng, Indonesia
}

\section{ABSTRACT}

Background: Poor access to contraceptive services is a global health problem, especially in the marginal community order. Refugee camps and areas with weak community order are the groups with the lowest prevalence of contraceptive use. This study aimed to determine the factors affecting contraceptive use in East Timorese ex-refugee women.

Subjects and Method: This was a crosssectional study conducted at 3 ex-refugee camps Noelbaki village, Kupang, East Nusa Tenggara, Indonesia, from April to May 2019. A total of 76 women of reproductive age were selected by fixed disease sampling. The dependent variable was contraceptive use. The independent variables were education, family income, accessibility, and social culture. The data were collected by a set of questionnaire and analyzed by a multiple logistic regression.

Results: The likelihood of contraceptive use increased with high education $(\mathrm{OR}=7.05 ; 95 \%$
$\mathrm{CI}=1.16$ to $42.76 ; \mathrm{p}=0.034)$, family income $(\mathrm{OR}=9.36 ; 95 \% \mathrm{CI}=0.88$ to $99.01 ; \mathrm{p}=0.063)$, accessible $(\mathrm{OR}=27.53 ; 95 \% \quad \mathrm{CI}=2.62$ to 288.88; $\mathrm{p}=0.006$ ), and supportive social culture $(\mathrm{OR}=14.15 ; 95 \% \mathrm{CI}=2.14$ to $83.63 ; \mathrm{p}=$ o.006).

Conclusion: The likelihood of contraceptive use increases with high education, family income, accessible, and supportive social culture.

Keywords: contraceptive, social culture, exrefugee

\section{Correspondence:}

Maria Paula Marla Nahak. Nursing Study Program, Universitas Citra Bangsa, Kupang, East Nusa Tenggara, Indonesia. Email: marlanahak858@gmail.com. Mobile: +6282328282282.

\section{Cite this as:}

Nahak MPM, Meo MLN, Simon MG (2020). Contraceptive Use in East Timorese Ex-Refugee Women in Indonesia: Determinants and Barriers. J Matern Child Health. 05(04): 365-375. https://doi.org/10.-

26911/thejmch.2020.05.04.03.

\section{Journal of Maternal and Child Health is licensed under a Creative Commons}

Attribution-NonCommercial-ShareAlike 4.o International License.

\section{BACKGROUND}

WHO reported that there were 214 million women of reproductive age in the world had unmet needs for contraception, especially in poor and developing countries (World Health Organization, 2018b). Indonesia reported that a contraceptive prevalence rate (CPR) in women of reproductive age (15-49 years) was $63.6 \%$ (UNDESA, 2017).

Poor access to contraceptive services is a global health problem, especially in the marginal community order (Agbemenu et al., 2019). WHO reported that there were health gaps between social groups in society (World Health Organization, 2016). Conflicted countries, refugee areas, and areas with weak social order were the groups with the lowest prevalence of contraceptive use by $<30 \%$ (United Nations High Commissioner for Refugees, 2019).

The East Timorese ex-refugee women in Kupang Regency, Indonesia, is one of the groups that is vulnerable to health pro- 
blems. This related to the common problems often faced by refugees and exrefugees such as conflicts of land tenure (Dhosa and Ratumakin, 2019), poverty (Gagnon et al., 2002), stigmatization (Meo and Nahak, 2020), discrimination (World Health Organization, 2018a), sociodemographic problems (Agbemenu et al., 2019), and other socioeconomic issues (Nakirijja et al., 2018). It affected reproductive health issues, namely contraceptive use. Refugee women did not use contraception for various reasons such as difficult geographical and financial access, conflict in decision making, misinformation related to contraception (Haider and Sharma, 2012; Ackerson and Zielinski, 2017), status as refugees (Adebowale et al., 2013), ethnicity (Kabagenyi et al., 2016), as well as physical and psychological violence (Bishwajit and Yaya, 2018).

Contraception as one of the reproductive health problems of refugee women (Gagnon et al., 2002) was a component in sexual and reproductive health. This was a human right established in the International Conference on Population and Development since 1994 (IAWG, 2018). It also contained in SDGs related to universal access to sexual and reproductive health services (Government of South Australia \& World Health Organization, 2017). The rights of sexual and reproductive health ensure that women have the right and responsibility to determine freely the amount, distance, when to have children, and the right to obtain information and standards of sexual and reproductive health to the highest (United Nations Fund for Population Activities, 2016). In addition, wide access to information about contraceptive methods must be provided. The women also have freedom to choose contraceptives without coercion, discrimination, or violence (Uni- ted Nations Fund for Population Activities, 2016).

Contraception as a human right should be an essential service for marginalized groups including ex-refugee women. However, nowadays, $53.1 \%$ of women of reproductive age in West Timor, Indonesia, have not used contraception (Meo and Nahak, 2020). Kupang Regency Government in 2018 reported that the Kupang Regency CPR rate was 59.6\%. It shows that the access to contraception is still an important issue in ex-refugee women of reproductive age who are still living in the settlement in Noelbaki Village, Kupang Regency, Indonesia.

As a major problem in poor and developing countries, not using contraception affected unwanted pregnancy, repetitive teenage pregnancy, high abortion rates, and sexually transmitted infections (Bishwajit \& Yaya, 2018).

This study aimed to determine the factors affecting contraceptive use in East Timorese ex-refugee women in Noelbaki Village, Kupang Regency, Indonesia.

\section{SUBJECTS AND METHOD}

\section{Study Design}

This was a cross-sectional study conducted at 3 refugee camps in Noelbaki Village, Kupang, East Nusa Tenggara, Indonesia, from April to May 2019.

\section{Population and Sample}

The population of this study was East Timorese ex-refugee women of reproductive age aged 15-49 years. A sample of 76 women was selected by fixed disease sampling. This method was a sampling technique based on disease status. Besides, exposure status varied according to the subject's disease status. The fixed disease sampling method emphasized that there were sufficient subjects in the case and control groups. 


\section{Study Variables}

The dependent variable was contraceptive use. The independent variables were education, family income, accessibility, and social culture.

\section{Operational Definition of Variables} Contraceptive use was the practice of using contraceptives to prevent pregnancy and keep the duration of birth. The data were collected by questionnaire, containing the choice of using contraceptive or not. If the women used contraceptive, it would be followed by a choice of contraceptive type and duration. The measurement scale was categorical, coded o for did not use contraceptive and 1 for use contraceptive.

Education was a formal education level reached by women of reproductive age. The data were collected by questionnaire. The measurement scale was categorical, coded o for low education and 1 for high education.

Family income was a cumulative income from all family members used to meet shared and individual needs. The data were collected by questionnaire. The measurement scale was continous, and transformed into dichotomous, coded o for low income $(<\operatorname{Rp} 1,800,000)$ and 1 for high income ( $\geq$ Rp 1,800,000).

Accessibility was the involvement of exrefugees women of reproductive age in the Integrated Service Post for women of reproductive age, and the affordability of women of reproductive age in accessing information and services regarding contraception. The data were collected by questionnaire. The measurement scale was continous, and transformed into dichotomous, coded o for poor accessibility and 1 for good accessibility.

Socio cultural was the community's point of view, the family values and norm, the perceptions of the surroundings about the benefits and the advantages of contraceptive use, and the local customs habits about contraceptive. The data were collected by questionnaire. The measurement scale was continous, and transformed into dichotomous, coded o for poor accessibility and 1 for unsupportive and 1 for supportive.

\section{Data Analysis}

Univariate analysis generally described the variables and the characteristics of the study subjects such as the education of women of reproductive age, family income, accessibility, social culture, age of women of reproductive age, occupation of women of reproductive age, number of children that still alive, and the number of family members living in the same house. Univariate analysis was described in the frequency and percentage form.

Bivariate analysis explained the effect of each independent variable on contraceptive use. The data were analyzed using a Chisquare Test.

Multivariate Analysis aimed to explain the effect of all independent variables on contraceptive use. The data were analyzed using a multiple logistic regression run.

\section{RESULTS \\ 1. Univariate Analysis}

Table 1 described the categorical data for each variable and the characteristics of the sample such as age, education, family income, accessibility, social culture, occupation, number of children, and number of family members who lives in the same house.

Table 1 showed that half of sample were at age 26-35 years (55.3\%). One third of sample (36.8\%) completed high school education. Most of the sample worked as housewives (89.5\%). Half of sample had family income <the minimum wage of Kupang Regency (59\%). Half of women (55.3\%) had $\geq 2$ children who still alive and $67.1 \%$ of the sample had $\geq 4$ family members who lived together in the same house. 
Nahak et al./ Contraceptive Use in East Timorese Ex-Refugee Women in Indonesia

As many as $69.7 \%$ women had poor access

received unsupportive social cultural to the health service. Half of sample $56.6 \%$.

Table 1. Sample Characteristics

\begin{tabular}{|c|c|c|}
\hline Characteristics & $\mathbf{n}$ & $\%$ \\
\hline \multicolumn{3}{|c|}{ Maternal age (years) } \\
\hline $17-25$ & 19 & 25.0 \\
\hline $26-35$ & 42 & 55.3 \\
\hline $36-45$ & 14 & 18.4 \\
\hline $46-55$ & 1 & 1.3 \\
\hline \multicolumn{3}{|c|}{ Maternal Education } \\
\hline Ungraduated & 14 & 18.4 \\
\hline Primary School & 18 & 23.7 \\
\hline Junior High School & 13 & 17.1 \\
\hline Senior High School & 28 & 36.8 \\
\hline Bachelor & 3 & 3.9 \\
\hline \multicolumn{3}{|c|}{ Maternal Occupation } \\
\hline Housewife & 68 & 89.5 \\
\hline Labor & 2 & 2.6 \\
\hline Private Employee & 5 & 6.6 \\
\hline Honorary worker & 1 & 1.3 \\
\hline \multicolumn{3}{|l|}{ Family Income } \\
\hline$<\operatorname{Rp~1,800,000}$ & 59 & 77.6 \\
\hline$\geq \operatorname{Rp} 1,800,000$ & 17 & 22.4 \\
\hline \multicolumn{3}{|c|}{ Number of family members } \\
\hline$<4$ & 51 & 67.1 \\
\hline$\geq 4$ & 25 & 32.9 \\
\hline \multicolumn{3}{|c|}{ Number of children that still alive } \\
\hline$<2$ & 42 & $55 \cdot 3$ \\
\hline \multicolumn{3}{|l|}{ Accessibility } \\
\hline Poor & 53 & 69.7 \\
\hline Good & 23 & 30.3 \\
\hline \multicolumn{3}{|l|}{ Social culture } \\
\hline Unsupportive & 43 & 56.6 \\
\hline Supportive & 33 & 43.4 \\
\hline
\end{tabular}

\section{Bivariate Analysis}

Table 2 showed the results of bivariate analysis using Chi-square. Table 2 showed that contraceptive use increased with high education $(\mathrm{OR}=32.66 ; \mathrm{p}<0.001)$, high family income $(\mathrm{OR}=26.90 ; \mathrm{p}<0.001)$, good accessibility $(\mathrm{OR}=22.23 ; \mathrm{p}<0.001)$, and supportive social culture $(\mathrm{OR}=4.29 ; \mathrm{p}=$ 0.005).

\section{Multivariate Analysis}

Table 3 shows that high education of $(\mathrm{OR}=$ 7.05; 95\% CI= 1.16 to $42.76 ; \mathrm{p}=0.034)$, good accessibility $(\mathrm{OR}=27.53 ; 95 \% \mathrm{CI}=$ 2.62 to $288.88 ; \mathrm{p}=0.006$ ), supportive social culture $(\mathrm{OR}=14.15 ; 95 \% \mathrm{CI}=2.14$ to 83.63; $\mathrm{p}=0.006$ ), and high family income $(\mathrm{OR}=9.36 ; 95 \% \mathrm{CI}=0.88$ to $99.01 ; \mathrm{p}=$ o.063) increased contraceptive use. 
Nahak et al./ Contraceptive Use in East Timorese Ex-Refugee Women in Indonesia

Table 2. The Result of Bivariate Analysis

\begin{tabular}{|c|c|c|c|c|c|c|c|c|c|}
\hline \multirow{3}{*}{$\begin{array}{c}\text { Independent } \\
\text { Variables }\end{array}$} & \multicolumn{4}{|c|}{ Contraceptive Use } & \multirow{2}{*}{\multicolumn{2}{|c|}{ Total }} & \multirow{3}{*}{$\mathbf{O R}$} & \multirow{3}{*}{$\begin{array}{c}95 \% \\
\text { CI }\end{array}$} & \multirow{3}{*}{$\mathbf{p}$} \\
\hline & \multicolumn{2}{|c|}{ Not Use } & \multicolumn{2}{|c|}{ Use } & & & & & \\
\hline & $\mathbf{n}$ & $\%$ & $\mathbf{n}$ & $\%$ & $\mathbf{N}$ & $\%$ & & & \\
\hline Maternal & & & & & & & & & \\
\hline Education & 35 & 46.1 & 10 & 13.1 & 45 & 59.2 & 32.66 & 8.1 to & $<0.001$ \\
\hline $\begin{array}{l}\text { Low } \\
\text { High }\end{array}$ & 3 & 3.9 & 28 & 36.7 & 31 & 40.8 & & 130.1 & \\
\hline Family Income & & & & & & & & & \\
\hline$<\operatorname{Rp} 1,800,000$ & 37 & 48.7 & 22 & 28.9 & 59 & 77.6 & 26.90 & 3.3 to & $<0.001$ \\
\hline $\begin{array}{l}\geq \operatorname{Rp} 1,800,000 \\
\text { Accessibility }\end{array}$ & 1 & 1.3 & 16 & 21 & 17 & 22.4 & & 217.1 & \\
\hline Poor & 36 & 47.3 & 17 & 22.4 & 53 & 69.7 & 22.23 & 4.6 to & $<0.001$ \\
\hline Good & 2 & 2.6 & 21 & 27.6 & 23 & 30.3 & & 105.9 & \\
\hline Socio Cultural & & & & & & & & & \\
\hline Unsupportive & 28 & 36.8 & 15 & 19.6 & 43 & 56.64 & 4.29 & 1.6 to & 0.005 \\
\hline Supportive & 10 & 13.1 & 23 & 30.3 & 33 & 3.4 & & 11.3 & \\
\hline
\end{tabular}

\section{DISCUSSION}

1. The effect of education on contraceptive use in ex-refugee women

The education of women of reproductive age had a positive effect on contraceptive use. The women of reproductive age with higher education used contraception 7.05 times higher than the women of reproductive age with low education. It showed that education was one of the factors affecting the decision of the women of reproductive age to use contraception. The higher the education reached by a woman, the higher the awareness to use contraception. Vice versa, the lower the education of a woman, the smaller the desire to use contraception.

Education was related to the ability to sort out information including the advantages and disadvantages of using contraception. WHO stated that education problems increased the risk of poor access to contraceptive services (World Health Organization, 2019). Women with higher education were three times more likely to use contraception than women who have never taken formal education (Rada, 2014; Adeyemi et al., 2016). This is in line with a study conducted by Wado (2017), that women with a higher level of education were more likely to use contraception.

The complexity of the reproductive health problems in East Timorese ExRefugee Women was difficult to describe. Poverty made this unfavorable cycle unavoidable. Besides, with high education, a woman became educated, so that she was able to make choices based on the information about contraception. In addition, education made a woman have a proper job and earned a good income, thus having the opportunity to improve her reproductive health.

\section{The effect of family income on contraceptive use}

Family income had a positive effect on contraceptive use. Women of reproductive age with high family income had likelihood to use contraception 9.36 times higher than those with low family income. It showed that high family income is in line with good financial access to contraceptive use. Vice versa, if the family income was low, it would affect the low contraceptive use.

Based on a previous study, the socioeconomic component could give an impact on women's access to contraceptive use (Nakirijja et al., 2018). Women with a good 
family finance could access contraception (Wado, 2017). In addition, women with low incomes were 1.6 times more likely to have unmet needs compared to women with higher education (Nakirijja et al., 2018).

Low income occurred due to the occupation that did not give a proper wage (Yesgat et al., 2020). This study showed that the majority of women of reproductive age worked as housewives. Based on the result of a previous study conducted by Dhosa and Ratumakin (2019), ex-refugee women in the 3 settlements worked as day workers for landowners to support the family economy. The women cleaned up the vegetables before being sold to the market. The daily wages received by these women ranged from Rp. 5000-8000 each day depending on the price of vegetables in the market.

This low income was getting worse with a large number of children that still alive. by a large number of living children. The result showed that most of the women of reproductive age had more than 2 children who still alive. This affected the family economy, both the fulfillment of daily needs, children's education costs, and respondents' financial access to contraception. Gebresilassie and Woldu (2018) proved that the number of children that still alive affected contraceptive use. Furthermore, Mahumud et al., (2015) proved that contraception discontinuity mostly occurred in poor people who lived in rural areas.

\section{The effect of accessibility on contraceptive use}

Accessibility had a positive effect on contraceptive use. Women of reproductive age with good accessibility used contraception 27.53 times higher than those with poor accessibility.

Integrated Services Post was a center of community activities that was conducted regularly. This activity was a form of health effort managed by the community. Through the involvement at the Integrated Services Post, the women of reproductive age could obtain information and services of $\mathrm{KB}$ through appropriate contraceptive selection counseling. The result of this study showed that most of the women of reproductive age had poor accessibility. This showed that women of reproductive age did not get sufficient information about contraception.

Meo and Nahak (2020) reported that there were differences in the level of respondents' participation in the Integrated Services Post held in the 3 settlements. The highest level of participation was the Integrated Services Post of BBI. In the Integrated Services Post of BBI, women of reproductive age were served by fellow exrefugee residents. Besides, the Integrated Services Post of Terminal was served by the local residents. The low level of participation was caused by different feelings in terms of the service received. In addition, the attitude of health service providers also contributed to the low participation of the community in the Integrated Services Post for women of reproductive age. According to Meo and Nahak (2020), refugee women were described as "lazy groups" and "unmanageable" by health workers. This is in line with a study conducted by (Merki-Feld et al., 2018), that both cadres and health workers tend to ignore the rights of refugee women to information of contraception in general. This is supported by the result of a study (Lowe, Griffiths and Sidhu, 2007; Pazol et al., 2016; Finlay and James, 2017), that service provider attitude affected contraceptive use. This omission disguised the main intervention that contraceptive counseling was the main key to increase contraceptive use and reduce the unmet need (Cavallaro et al., 2019).

In addition, other obstacles were poor service quality (Sinai et al., 2018) and 
misperceptions related to modern contraception (Tran et al., 2018) which made the reproductive health problems of ex-refugee women getting worse, especially in the contraceptive services.

Therefore, the approach that needs to do is a service that is respectful and nondiscriminatory, so that the refugee women have the motivation and willingness to access Integrated Service Post services. In addition, the women are able to make choices regarding contraception based on information received. Integrated Service Post as a community-based health effort should empower more refugee groups to provide information regarding contraception with language styles and counseling techniques that are in accordance with refugee conditions.

\section{The effect of social cultural on contraceptive use}

Socio cultural had a positive effect on contraceptive use. Women of reproductive age with a supportive socio-cultural to use contraception was 14.15 times higher than women of reproductive age with unsupportive socio-cultural. It showed that women with supportive socio-cultural, tend to use contraception compared to women of reproductive age with unsupportive sociocultural.

Nowadays, even though there are many improvements related to the availability of contraceptives, women still face persistent obstacles related to reproductive autonomy and informed choice (Dehlendorf et al., 2018; Pleasants et al., 2019).

Based on a previous study, there was a prohibition by husband, mother, and mother-in-law because contraceptive use was considered to limit the offspring. In addition, there were wrong perceptions that were built based on the experience of family members who had used contraception. Based on the study result on the persistent barriers and unmet need for contraceptive use, women were reluctant to use contraception due to cultural and language barriers between women of reproductive age and health providers (Tanabe et al., 2017), lack of husband's agreement (Richardson et al., 2016), and fear or previous experience related to side effects of contraceptive use (Wyatt et al., 2014). In addition, discrimination from fellow refugee women also inhibits access to contraception.

The description of women's greatest fears is low self-esteem and fear of being criticized by fellow women under the statement "the woman does not want to give a child to her husband anymore" or "she is not a woman and the stigma given by fellow women that using contraception means being unable to manage the family (Alspaugh et al., 2019).

Family (Thapa et al., 2018), husband (Hodgson et al., 2013), as well as the desire to maintain culture were factors that inhibit a woman from using contraception. It often occurred in crisis and ethnocentric areas (World Health Organization, 2019). Therefore, a $\mathrm{KB}$ counseling by involving husband and family members is very useful. Open discussion between families and health service providers was the key to increase contraceptive use among ex-refugee women (Gebresilassie and Woldu, 2018) because the opinions of husbands and mothers affected the health value of a woman (Bell et al., 2020; Richards et al., 2020) al., 2020). Well-informed husbands and family members were expected to have an impact on making the right decisions (World Health Organization, 2016; Jain et al., 2017; Dadi et al., 2020).

The problems faced by East Timorese ex-refugee women are complex. Poverty, lack of land, and barriers to health services are a life cycle that will occur repeatedly. Refugee women who are mostly live in the 
poverty chain should be given the wide right to become agents of change in their communities. Women of reproductive age must be given the same right to receive education, to find proper job without any discrimination and verbal violence. This cycle is expected to stop. In addition, the ex-refugee groups have a decent life, thus affecting the optimization of their sexual and reproductive health.

\section{AUTHOR CONTRIBUTION}

Maria Paula Marla Nahak collected the data and wrote the manuscriot. Maria Lupita Nena Meo and Maria Getrida Simon did data analysis and read the data interpretation.

\section{CONFLICT OF INTEREST}

The authors declare that the study was conducted in the absence of any commercial or financial relationships that could be construed as a potential conflict of interest.

\section{FUNDING AND SPONSORSHIP}

This study was a part of a series of studies with the theme of "Study of Reproductive Health of East Timorese Ex-Refugee Women in Noelbaki Village, Kupang, East Nusa Tenggara, Indonesia, funded by the Ministry of Research, Technology and Higher Education through research designs for beginner lecturers in 2019.

\section{ACKNOWLEDGEMENT}

The researcher would like to thank the Ministry of Research, Technology and Higher Education for funding this study.

\section{REFERENCE}

Ackerson K, Zielinski R (2017). Factors influencing use of family planning in women living in crisis affected areas of Sub-Saharan Africa: A review of the literature. Midwifery. 54: 35-60. https://doi.org/10.1016/j.midw.2017. 07.021.

Adebowale SA, Adeoye IA, Palamuleni ME (2013). Contraceptive use among Nigerian women with no fertility intention: Interaction amid potential causative factors. Etude de La Population Africaine. 27(2): 127-139. https://doi.org/10.11564/27-2-435

Adeyemi AS, Olugbenga-Bello AI, Adeoye O, Salawu M, Aderinoye A, Agbaje M (2016). Contraceptive prevalence and determinants among women of reproductive age group in Ogbomoso, Oyo State, Nigeria. Open Access Journal of Contraception, 33. https://doi.org/10.2147/oajc.s94826

Agbemenu K, Auerbach S, Murshid NS, Shelton J, Amutah-Onukagha N (2019). Reproductive health outcomes in African refugee women: A comparative study. Journal of Women's Health, 28(6): 785-793. https://doi.org/10.1089/jwh.2018.7314.

Alspaugh A, Barroso J, Reibel M, Phillips S (2019). Women's contraceptive perceptions, beliefs, and attitudes: An integrative review of qualitative research. Journal of Midwifery and Women's Health, 65(1): 64-84. https://doi.org/10.1111/jmwh.12992.

Bell AV, Gifford K, Rashid H, McDuffie MJ, Knight EK (2020). "Power of mom": A mixed methods investigation of mothers' influence on women's contraceptive attitudes and behaviors. Maternal and Child Health Journal, 24(3): 291-298. https://doi.org/10.1007/s10995-019-02859-5.

Bishwajit G, Yaya S (2018). Domestic violence: a hidden barrier to contraceptive use among women in Nigeria. Open Access Journal of Contraception. 9: 21-28. https://doi.org/10.2147/oajc.s154733. 
Nahak et al./ Contraceptive Use in East Timorese Ex-Refugee Women in Indonesia

Cavallaro FL, Benova L, Owolabi OO, Ali M (2019). A systematic review of the effectiveness of counselling strategies for modern contraceptive methods: What works and what doesn't? BMJ Sexual and Reproductive Health. 7: 116. https://doi.org/10.1136/bmjsrh-2019-200377.

Dadi D, Bogale D, Minda Z, Megersa S (2020). Decision-making power of married women on family planning use and associated factors in Dinsho Woreda, South East Ethiopia. Open Access Journal of Contraception. 11: 15-23. https://doi.org/10.2147/oajc.S225331.

Dehlendorf C, Reed R, Fox E, Seidman D, Hall C, Steinauer J (2018). Ensuring our research reflects our values: The role of family planning research in advancing reproductive autonomy. Contraception, 98(1). https://doi.org/10.1016/j.contraception.2018.03.015

Dhosa DD, Ratumakin PA (2019). Ekonomi politik redistribusi tanah, dinamika kelas dan perjuangan pengungsi Timor Timur di Timor Barat Indonesia. Jurnal Pendidikan Dan Kebudayaan Missio. 11(1): 1-17. Retrieved from https://www.ejournal.stkipsantupaulus.ac.id/index.php/jpkm/articl e/.

Finlay JE, James E (2017). Barriers to contraceptive use: Examination of contraceptive laws and contraceptive use in Sub-Saharan Africa. Journal of Contraceptive Studies, 02(02): 1-10. https://doi.org/10.21767/2471-9749.100031.

Gagnon AJ, Merry L, Robinson C (2002). A systematic review of refugee women's reproductive health. Refuge - Canada's Periodical on Refugees. 21(1): 6-17. https://doi.org/10.25071/19207336.21279 .
Gebresilassie YH, Woldu GT (2018). Explaining unmet need for family planning in rural Tigrai, Ethiopia. Journal of Contraceptive Studies. 03(02): 1-7. https://doi.org/10.21767/2471-9749.100047.

Government of South Australia and World health Organization (2017). Progressing the Sustainable Development Goals through Health in All Policies: Case Studies from Around the World. In Government of South Australia. https://doi.org/10.1002/hpja.230.

Haider T, Sharma M (2012). Barriers to family planning and contraception uptake in Sub-Saharan Africa: A systematic review. International Quarterly of Community Health Education. 33(4): 403-413. https://doi.org/10.2190/IQ.33.4.g.

Hodgson EJ, Collier C, Hayes L, Curry LA, Fraenkel L (2013). Family planning and contraceptive decision-making by economically disadvantaged, AfricanAmerican women. Contraception. 88(2): 289-296. https://doi.org/10.1016/j.contraception.2012.10.011.

IAWG (2018). Inter-agency field manual on reproductive health in humanitarian settings. Available at https://resourcecentre.savethechildren.net/node/11 145/pdf/iafm_on_reproductive_health_in_hs_2018.pdf

Jain A, Reichenbach L, Ehsan I, Rob U (2017). "Side effects affected my daily activities a lot": a qualitative exploration of the impact of contraceptive side effects in Bangladesh. Open Access Journal of Contraception. 8: 45-52. https://doi.org/10.2147/oajc.S140214.

Kabagenyi A, Habaasa G, Rutaremwa G (2016). Low contraceptive use among young females in Uganda: Does birth history and age at birth have an influ- 
Nahak et al./ Contraceptive Use in East Timorese Ex-Refugee Women in Indonesia

ence? Analysis of 2011 Demographic and Health Survey. J Contracept Study. 1(1): 4. https://www.ncbi.nlm.nih.gov/pubmed/28317036.

Lowe P, Griffiths F, Sidhu R (2007). "I got pregnant, I was so like ... crying inside ...": experiences of women of Pakistani ancestry seeking contraception in the UK. Diversity in Health and Social Care, 4: 69-76. Retrieved from http://www.radcliffe-oxford.com/journals/J18_Diversity_in_Health_and_Soc ial_Care/.

Mahumud RA, Hossain G, Sarkar AR, Islam N, Hossain R, Aik S, Khan J (2015). Prevalence and associated factors of contraceptive discontinuation and switching among Bangladeshi married women of reproductive age. Open Access J Contracept. 13. https://doi.org/10.2147/oajc.s76070.

Meo MLN, Nahak MPM (2020). Problem kesehatan reproduksi perempuan usia subur eks pengungsi Timor Timur. Jurnal Kesehatan Reproduksi, 7(1): 18-25. https://doi.org/10.22146/jkr.47128 .

Merki-Feld GS, Caetano C, Porz TC, Bitzer J (2018). Are there unmet needs in contraceptive counselling and choice? Findings of the European TANCO Study. Eur J Contracept Reprod Health Care. 23(3): 183-193. https://doi.org/10.1080/13625187.2018.1465546.

Nakirijja DS, Xuili X, Kayiso MI (2018). Socio-economic determinants of access to and utilization of contraception among rural women in Uganda: The Case of Wakiso District. Health Science Journal, 12(6): 1-20. https://doi.org/10.21767/1791-809x.1000608.

Pazol K, Zapata LB, Tregear SJ, MautoneSmith N, Gavin LE (2016). Impact of contraceptive education on contraceptive knowledge and decision making: A systematic review. Physiology \& Behavior, 176(1): 139-148. https://doi.org/10.1016/j.physbeh.2017.03.040.

Pleasants E, Koffi TB, Weidert K, McCoy SI, Prata N (2019). Are women in Lomé getting their desired methods of contraception? Understanding provider bias from restrictions to choice. Open Access J Contracept. 10: 79-88. https://doi.org/10.2147/oajc.s226481.

Rada C (2014). Family planning in Romania: A cross-sectional study of knowledge, practice and attitudes. International Journal of Collaborative Research on Internal Medicine \& Public Health, 6(9): 260-275.

Richards NK, Crockett E, Morley CP, Levandowski BA (2020). Young women's reproductive health conversations: Roles of maternal figures and clinical practices. PLoS ONE, 15(1): 111. https://doi.org/10.1371/journal.pone.0228142.

Richardson E, Allison K, Gesink D, Berry A (2016). Barriers to accessing and using contraception in highland Guatemala: the development of a family planning self-efficacy scale. Open Access J Contracept. 77-87. https://doi.org/10.2147/oajc.s95674.

Sinai, I, Nyenwa J, Oguntunde O (2018). Programmatic implications of unmet need for contraception among men and young married women in northern Nigeria. Open Access J Contracept. 9: 81-90. https://doi.org/10.2147/oajc.s172330

Tanabe M, Myers A, Bhandari P, Cornier N, Doraiswamy S, Krause S (2017). Family planning in refugee settings: findings and actions from a multicountry study. Conflict and Health. 1- 
Nahak et al./ Contraceptive Use in East Timorese Ex-Refugee Women in Indonesia

12. https://doi.org/10.1186/s13031017-0112-2

Thapa P, Pokharel N, Shrestha M (2018). Knowledge, attitude and practices of contraception among the married women of reproductive age group in selected wards of Dharan Sub-Metropolitan City. J Contracept Studies, 03(03): 1-8. https://doi.org/10.21767/2471-9749.100051.

Tran NT, Yameogo WME, Gaffield ME, Langwana F, Kiarie J, Kulimba M, Seni K (2018). Postpartum familyplanning barriers and catalysts in Burkina Faso and the Democratic Republic of Congo: a multiperspective study. Open Access J Contracept. 9: 63-74. https://doi.org/10.2147/oajc.s170150.

UNDESA. (2017). World Family Planning. United Nations, 1-43. Available at https://www.un.org/en/development /desa/population/publications/pdf/fa mily/WFP2017_Highlights.pdf

United Nations Fund for Population Activities. (2016). Universal access to reproductive health : Progress and challenges. UNFPA, January. Available at https://www.unfpa.org/sites/default/ files/pub-pdf/UNFPA_Reproductive_Paper_20160120_online.pdf

United Nations High Commisioner for Refugees. (2019). Contraception and family planning in refugee settings. UNHCR. Available at https://www.unhcr.org/5e53af2c4.pdf

Wado YD (2017). Women's autonomy and reproductive health-care-seeking behavior in Ethiopia. Women and Health, 58(7): 729-743. https://doi.org/10.1080/o3630242.2017.1353573

World Health Organization (2016). Selected practice recommendations for contraceptive use. Third Edition. Available at https://apps.who.int/iris/bitstream/handle/10665/252267/97892415 65400-eng.pdf;jsessionid=AFA5066F3AA385411DA48E888430D7CE?seq uence $=1$.

World Health Organization (2018a). Family planning: A global handbook for providers. 2018 Edition. Available at https://www.fphandbook.org/sites/d efault/files/global-handbook-2018full-web.pdf

World Health Organization (2018b). Family planning/ Contraception. 1-8. Available at https://www.who.int/newsroom/fact-sheets/detail/family-planning-contraception

World Health Organization (2019). Contraception. World Health Organization. https://doi.org/10.1136/bmj.2.3892.2 65 Available at https://apps.who.int/iris/bitstream/handle/10665/32988 4/WHO-RHR-19.18-eng.pdf?ua=1.

Wyatt KD, Anderson RT, Creedon D, Montori VM, Bachman J, Erwin P, LeBlanc A (2014). Women's values in contraceptive choice: A systematic review of relevant attributes included in decision aids. BMC Women's Health, 14(1): 1-18. https://doi.org/10.1186/1472-6874-14-28

Yesgat YM, Gebremeskel F, Estifanous W, Gizachew Y, Jemal S, Atnafu N, Nuriye $K$ (2020). Utilization of family planning methods and associated factors among reproductive-age women with disability in Arba Minch Town, Southern Ethiopia. Open Access J Contracept. 11: 25-32. https://dx.doi.org/10.2147\%2FOAJC.S24081 7 